\title{
TAT TWAM ASI DAN SOLUSI MASALAH STUDY CHANDOGYA UPANISAD
}

\author{
Putu Dian Tika \\ Jalan Ratna, Gg.Werkudara, N0.7, Denpasar \\ Email : putudiantika98@gmail.com
}

\begin{abstract}
:
Mahavakya tat twam asi is contained in the chandogya upanisad 6.8.7 "which means: you are it; You are all that; All beings are You. You are the beginning of jiwatman (spirit) and substance (prakrti) of all beings. Therefore my soul and your soul are single with the soul of all beings, and you are my source and the source of all beings. Therefore I am you, and vice versa. There are still a few Hindus who understand the meaning of Tat Twam Asi. Even though Tat Twam Asi is the Teachings of the similarity of Human Dignity or the Teachings of the Brotherhood. True, indeed all humans are brothers and sisters as a big family of the world, because the Atman of every human being is the same, namely the spark of the divine light of the Almighty God. Therefore there is also interpreting Tat Twam Asi as my Atman is your Atman, on the contrary your Atman is my Atman but there are also those who interpret Tat Twam Asi as the Doctrine of Compassion, where a large number of human beings must love one another, help each other and sharpen each other, love each other and fostering each other, so that life and human life become harmonious, safe, peaceful and peaceful.
\end{abstract}

Keywords: tat tvam asi, Chandogya Upanisad, solution, problem

\begin{abstract}
Abstrak:
Mahavakya tat twam asi termuat dalam chandogya upanisad 6.8.7" yang berarti: Dikaulah itu; Dikaulah semua itu; Semua makhluk adalah Engkau. Engkau awal mula jiwatman (roh) dan zat (prakrti) semua makhluk. Aku ini adalah makhluk yang berasal dari Mu. Oleh karena itu jiwatmaku dan prakrtiku tunggal dengan jiwatman semua makhluk, dan Dikau sebagai sumberku dan sumber semua makhluk. Oleh karena itu aku adalah Engkau, begitupun sebaliknya. Umat Hindu masih sedikit yang mengerti makna Tat Twam Asi. Padahal Tat Twam Asi merupakan Ajaran Kesamaan Martabat manusia atau Ajaran Persaudaraan. Benar, memang semua manusia adalah bersaudara, bersaudara sebagai keluarga besar dunia, karena Atman setiap manusia adalah sama, yaitu percikan sinar suci Tuhan Yang Maha Kuasa. Karena itu ada juga memaknai Tat Twam Asi sebagai Atmanku adalah Atmanmu, sebaliknya Atmanmu adalah Atmanku tetapi ada juga yang mengartikan Tat Twam Asi sebagai Ajaran Kasih Sayang, dimana umat manusia yang jumlahnya banyak sekali harus saling mengasihi,saling menolong dan saling asah, saling asih dan saling asuh, sehingga hidup dan kehidupan manusia menjadi harmonis, aman, tentram, dan damai.
\end{abstract}

Kata Kunci: tat tvam asi, Chandogya Upanisad, solusi, masalah

\section{I.Pendahuluan}

Secara etimologi, Tat Twam Asi berasal dari bahasa Sanskerta yang terdiri dari tiga kata, yakni Tat, Twam, dan Asi. "Tat" merupakan kata penunjuk, "itu". "Twam" artinya "engkau”, dan "Asi" mempunyai arti "adalah". Dengan demikian, Tat Twam Asi dapat diartikan sebagai itu adalah engkau, atau sering disebut juga sebagai aku adalah engkau. Menurut Sudharta dalam (Karda, I Made dkk, 2007:18) menyebutkan bahwa 
: Tat Twam Asi adalah kata-kata filsafat dalam agama Hindu yang mengajarkan kesosialan yang tanpa batas karena diketahui bahwa "ia adalah kamu" saya adalah kamu dan segala makhluk adalah sama sehingga menolong orang lain berarti menolong diri sendiri dan menyakiti orang lain berarti menyakiti diri sendiri. Sementara menurut Sukartha dkk. (2002:67), Tat Twam Asi berasal dari bahasa Sansekerta yang tertuang dalam Chandogya Upanisad. Dijelaskan bahwa kata Tat berarti "Itu" atau "Dia" Twam Berarti "Engkau" atau "Kamu" dan Asi berarti "Adalah" jadi tat Twam Asi diartikan menjadi Dia Adalah Kamu.

Konsep Tat Twam Asi sendiri tersurat dalam Chandogya Upanisad 6.8.7, yang mana mengisahkan bahwa ada seorang anak bernama Svetaketu yang merupakan murid sekaligus putra dari Uddalaka yang merasa sombong dan menganggap dirinya paling hebat karena telah membaca Veda dan merasa telah mengenal Tuhan. Pada akhirnya, Svetaketu disadarkan oleh ayahnya bahwa realitas tersebut tunggal adanya dan tidak terpecah-pecah. Begitu pula dengan manusia dan alam yang juga merupakan satu kesatuan dengan Tuhan. Tat Twam Asi merupakan intisari dari 888iajaran Upanisad yang menjelaskan bahwa manusia bukanlah suatu entitas yang terpisah dengan Tuhan dan alam semesta, namun merupakan satu kesatuan. Hal ini sangatlah jelas karena antara Brahman (Paramātman) dan Atman perseorangan (Jivātman) sesungguhnya sama. Seperti yang kita ketahui bahwa Atman merupakan percikan dari Brahman yang juga mempunyai unsur serta kualitas yang sama dengan Brahman, hanya saja ada yang membedakan, yakni ketika Atman tersebut lahir ke dunia karena Atman yang telah lahir ke dunia telah diliputi oleh Guna (Sattwam, Rajas, Tamas) dan terpengaruh oleh maya. . (Nataldevi,2015)

Umat Hindu masih sedikit yang mengerti makna Tat Twam Asi. Padahal Tat Twam Asi merupakan Ajaran Kesamaan Martabat manusia atau Ajaran Persaudaraan. Benar, memang semua manusia adalah bersaudara, bersaudara sebagai keluarga besar dunia, karena Atman setiap manusia adalah sama, yaitu percikan sinar suci Tuhan Yang Maha Kuasa. Karena itu ada juga memaknai Tat Twam Asi sebagai Atmanku adalah Atmanmu, sebaliknya Atmanmu adalah Atmanku tetapi ada juga yang mengartikan Tat Twam Asi sebagai Ajaran Kasih Sayang, dimana umat manusia yang jumlahnya banyak sekali harus saling mengasihi,saling menolong dan saling asah,saling asih dan saling asuh, sehingga hidup dan kehidupan manusia menjadi harmonis, aman, tentram, dan damai. (shaakuntala:2015)

Tetapi kenyataan tidaklah demikian. Bahkan banyak sekali warga masyarakat yang berselisih paham, menghadapi silang sengkata yang tidak kunjung padam, bahkan sampai tibul percekcokan Pertengkaran bahkan perkelahian dan peperangan. Itu disebabkan diri kita sendiri, sampai sejauh mana kita memahami, mengkhayati dan mengamalkan Ajaran Tat Twam Asi itu. Memang manusia banyak sekali perbedaanya, baik Ras, Profesi, Agama, Wangsa dan lain - lain. Namun perbedaan itu semestinya dapat direndam sedemikian rupa, sehingga kita semua dapat dijauhkan dari perselisihan dan perpecahan yang tidak perlu. Kesulitanya adalah pada pengendalian diri dan egoisme pribadi.

\section{PEMBAHASAN}

\section{Tat TramAsi Dalam Candoghya Upanishad}

Uddalaka memiliki seorang putra bernama Shvetaketu. Ketika dia berumur dua belas tahun, ayahnya berkata kepadanya, 'Inilah saatnya bagi Anda untuk menemukan seorang guru spiritual. Semua orang di keluarga ini telah mempelajari kitab suci dan jalan spiritual. ' Jadi Shvetaketu pergi ke seorang guru dan mempelajari tulisan suci selama dua belas tahun. Dia kembali ke rumah dengan sangat bangga dengan pengetahuan intelektualnya. Ayahnya mengamatinya dan berkata, 'Anakku, kamu tampaknya memiliki 
pendapat yang tinggi tentang dirimu sendiri; Anda bangga dengan pembelajaran Anda. Tetapi apakah Anda bertanya kepada guru Anda untuk pengetahuan spiritual yang memungkinkan Anda untuk mendengar yang tidak didengar, berpikir yang tidak terpikirkan dan mengetahui yang tidak diketahui? ' 'Apa pengetahuan itu, Ayah?' tanya Svetaketu. Sama seperti mengetahui segumpal tanah liat, segala sesuatu yang terbuat dari tanah liat dapat diketahui, karena setiap perbedaan hanyalah kata-kata, dan realitas esensial adalah tanah liat. Dengan cara yang sama dengan mengetahui sepotong emas, semua yang terbuat dari emas dapat diketahui, karena setiap perbedaan hanyalah kata-kata, dan kenyataannya hanya emas. ' Uddalaka menjawab, 'Para guru saya pasti tidak mengetahui hal ini atau mereka akan mengajarkannya kepada saya. Ayah, tolong ajari aku pengetahuan ini. “ "Aku akan melakukannya," jawab ayahnya. 'Pada awalnya hanya ada Being. Beberapa orang mengklaim bahwa pada mulanya tidak ada apa-apa dan bahwa semuanya telah keluar dari ketiadaan. Tapi bagaimana ini bisa benar? Bagaimana bisa itu, datang dari yang tidak ada? Pada mulanya hanya ada satu Wujud, dan Wujud itu berpikir, "Saya ingin menjadi banyak sehingga saya akan menciptakan." Dari ciptaan ini datanglah kosmos. Tidak ada apa pun di dalam kosmos yang tidak berasal dari Yang Berada itu. Dari semua yang ada, Keberadaan ini adalah Diri terdalam. Dia adalah kebenaran, Diri Tertinggi. Dan Anda, Shvetaketu, Anda adalah itu! ' Shvetaketu bertanya, 'Tolong ajari aku lebih banyak tentang Diri, Ayah.' 'Mari kita mulai dengan tidur. Apa yang terjadi ketika kita tidur? Ketika seseorang diserap dalam tidur tanpa mimpi, dia adalah satu dengan Diri meskipun dia tidak mengetahuinya. Kami mengatakan dia tidur tetapi kami berarti dia tidur di Self. Seperti seekor burung yang kakinya diikat tali dan sesudah terbang dari segala penjuru tanpa menemukan tempat beristirahat akhirnya akan bertengger di tempat dia terikat . Demikian juga pikiran setelah terbang dari segala penjuru tanpa menemukan tempat berpijak akan beristirahat pada nafas,sebab pikiran anakku terikat pada nafas, Semua makhluk memiliki sumbernya dalam Keberadaan itu. Dia adalah rumah mereka; Dia adalah kekuatan mereka. 'Ketika seorang pria sedang sekarat, ucapan terlipat ke dalam pikiran, pikiran melipat ke dalam kehidupan, kehidupan larut menjadi cahaya, dan cahayanya menyatu menjadi Yang itu. Makhluk itu adalah benih, kebenaran, Diri, dan Anda, Shvetaketu, Anda adalah itu! “ “Tolong ceritakan lebih banyak, Ayah." 'Putraku, lebah membuat madu dengan mengumpulkan nektar dari banyak bunga untuk membuat madu mereka, jadi tidak ada satu tetes madu pun yang dapat mengatakan bahwa itu berasal dari satu bunga tertentu. Anda tidak dapat mengidentifikasi jus dari satu bunga tertentu di dalam madu. Demikian juga dengan makhluk-makhluk seperti kita yang bergabung dengan Makhluk itu, baik dalam tidur maupun mati. 'Dan seperti sungai yang mengalir dari timur ke barat bergabung di laut dan menjadi satu dengan itu, lupa bahwa mereka pernah menjadi sungai yang terpisah, sehingga semua makhluk kehilangan keterpisahan mereka ketika mereka bergabung menjadi Wujud murni. Makhluk apa pun itu - harimau, singa, serigala, babi hutan, nyamuk, cacing - hanya menjadi sadar akan kehidupan tertentu ketika dilahirkan atau terjaga. 'Jika kamu menyerang pada akar pohon, itu akan berdarah tetapi masih hidup. Jika Anda menyerang di batang pohon, getahnya merembes, tetapi pohon itu hidup. Diri sebagai hidup mengisi pohon dan mendukungnya; itu berkembang dalam kebahagiaan mengumpulkan makanan melalui akarnya. Namun, jika kehidupan berangkat dari satu cabang, cabang itu layu, dan ketika kehidupan meninggalkan seluruh pohon, seluruh pohon layu. Ingat anakku, tubuhmu mati, tetapi dirimu tidak. 'Uddalaka memberi tahu Shvetaketu untuk membawakannya buah dari pohon beringin di dekatnya dan membukanya. Shvetaketu melakukan dan berkata, 'Ada biji di dalam, semuanya sangat kecil.' 'Sekarang, pecahkan salah satu biji dan beri tahu saya apa yang Anda lihat.' "Tidak ada 
apa-apa, Ayah." Uddalaka berkata, 'Putraku, pohon beringin besar ini tumbuh dari biji yang begitu kecil sehingga kau tidak bisa melihatnya. Percayalah, esensi yang tidak terlihat dan halus adalah Roh seluruh alam semesta. 'Sekarang, ambil garam ini dan taruh di air dan bawakan ke saya besok pagi.' Pagi berikutnya Shvetaketu mencari garam tetapi tidak dapat menemukannya karena sudah larut. Uddalaka meminta putranya untuk mencicipi air. "Asin," katanya, sambil menambahkan, 'garam akan selalu ada di air.' "Betul. Garam menembus air, sama seperti Diri. Meskipun kita tidak dapat melihatnya, Diri ada dalam segala hal dan tidak ada yang tidak datang dari-Nya. "Esensi yang tidak terlihat dan halus ini adalah Roh seluruh alam semesta. Itu kenyataan. Itu kebenaran. Dan Anda, Shvetaketu, anda adalah itu! Dalam Chandogya Upanishad ini dikatakan bahwa konsep "Tat twam asi" yang berarti: Dikaulah itu; Dikaulah semua itu; Semua makhluk adalah Engkau. Engkau awal mula jiwatman (roh) dan zat (prakrti) semua makhluk. Aku ini adalah makhluk yang berasal dari Mu. Oleh karena itu jiwatmaku dan prakrtiku tunggal dengan jiwatman semua makhluk, dan Dikau sebagai sumberku dan sumber semua makhluk. Oleh karena itu aku adalah Engkau,begitupun sebaliknya.

Di dalam filsafat Hindu, dijelaskan bahwa Tat twam asi adalah ajaran kesusilaan yang tanpa batas, yang identik dengan perikemanusiaan dalam pancasila. Konsepsi sila perikemanusiaan dalam pancasila, apabila kita cermati sungguh sungguh adalah merupakan realisasi ajaran Tat twam asi yang terdapat dalam pustaka suci Weda. Kalimat Tat twam asi mengandung makna bahwa manusia wajib dan harus mengasihi orang lain sebagaimana menyayangi diri kita sendiri. Inilah dasar utama untuk mewujudkan masyarakat yang Santhi (damai). Tat twam asi selalu mengamalkan cinta kasih, bakthi, dan rela beryadnya (berkorban). Dalam kitab suci dikatakan demikian: Hyang amati - mati wang tan padosa, haywa anglarani sarwa prani, haywa kita tan masih ring wang nista.
Artinya:Janganlah menyakiti makhluk hidup, janganlah tidak menaruh belas kasihan terhadap orang miskin atau orang yang ditimpa kemalangan. Cinta kasih sejati ditandai dengan cinta kepada kebenaran dan kebaikan, maka menjadi kewaijban setiap orang untuk berbuat baik dan benar. Bhakti adalah perwujudan hati nurani yang ditunjukkan kepada orang tua, guru, bangsa, dan negara serta Hyang Widhi.

Tat Twam Asi adalah ajaran moral yang bernafaskan agama Hindu. Wujud nyata dari ajaran ini dapat kita cermati dalam kehidupan dan prilaku keseharian dari umat manusia. Manusia dalam hidupnya memiliki berbagai macam kebutuhan hidup yang dimotifasi oleh keinginan manusia yang bersangkutan. Sebutan manusia sebagai makhluk hidup itu banyak jenis, sifat dan ragamnya, seperti manusia sebagai makhluk individu, social, religius, ekonomis, budaya, dan yang lainnya. Semua itu harus dapat dipenuhi oleh manusia secara menyeluruh dan bersamaan tanpa memperhitungkan situasi dan kondisi serta keterbatasan yang dimilikinya. Disinilah manusia perlu mengenal dan melaksanakan rasa kebersamaan, sehingga seberapa berat masalah yang dihadapi akan terasa ringan. Dengan memahami dan mengamalkan ajaran Tat Twam Asi, manusia akan dapat merasakan berat dan ringan dalam hidup dan kehidupan ini berdampingan adanya dan sulit dipisahkan keberadaannya. Dengan demikian maka dalam hidup ini kita hendaknya selalu saling tolong menolong, merasa senasib dan sepenanggungan.

Prilaku sebagai implementasi ajaran Tat Twam Asi jika diperinci ada tiga bentuk antara lain :

1) Hormat dan Kasih kepada Keluarga

- Hormat kepada Ibu Bapak

Didalam keluarga ada orang tua dan keluarga. Kepada semua itulah harus hidup saling menghormati, sehingga tidak ada permusuhan satu sama lain. Semua pihak harus menjalankan 
kesusilaan yang dilandasi dengan Tat Twam Asi. Hormat kepada orang tua itu seperti mendengarkan nasehatnya, saling menyayangi dan sebagainya.

\section{- Cinta kepada saudara.}

Bangunlah sikap Tat Twam Asi diantara saudara. Ini penting supaya tercipta suasana damai diantara saudara. Bila ada masalah supaya diselesaikan dengan musyawarah, masing-masing pihak harus mampu mengendalikan diri, tidak terbius oleh kama negatif seperti Sad Ripu dan sebagainya. Waspadai pihak ketiga yang mencoba menggoda kerukunan bersaudara.

1) Hormat kepada Guru dan Teman sekelas.

- Hormat kepada Guru.

Murid atau siswa harus hormat kepada orang tua (Guru Rupaka) juga kepada Guru Pengajian, karena merekalah yang mendidiknya agar dapat berkembang menjadi dewasa dalam berpikir, mengembangkan intelektualnya, memiliki rasa tanggung jawab, bermoral serta dapat berguna bagi nusa dan bangsa. Betapa hutang budhi yang dimiliki siswa yang tak mungkin bisa dibayar. Jasa Guru Pengajian amatlah besar, oleh karena itu rasa hormat kepada Guru sampai kapanpun perlu dipupuk. Tak dapat dibayangkan bagaimana jadinya seseorang jika tak berpendidikan. Oleh karena itu patuhi nasehat guru, rajin belajar dan jangan lupa segala bimbingannya.

\section{- Cinta kasih kepada teman.}

Seseorang tidak bisa huidup dalam kesendiriannya, ia butuh teman dari seseorang. Untuk itu seseorang perlu mencari teman. Dengan berteman seseorang akan dapat menjadi orang. Ada ungkapan bahwa teman yang baik adalah teman yang ingat pada saat dirinya mengalami kesusahan. Pada saat bahagia datang atau tidak, tak menjadi masalah. Tapi saat menderita teman itu perlu ditengok. Bila perlu dibantu. Kapan lagi membantu kalau tidak saat kesusahan. Itulah tanda persahabatan yang baik. Oleh karena itu pupuklah persahabatan itu dengan baik, hindari permusuhan, dengan saling mencintai, saling mengasihi, saling menolong, saling tenggang rasa persahabatan menjadi kekal. Persahabatan yang kekal akan banyak memberi manfaat dalam kehidupan ini.

2) Cinta Kasih kepada Lingkungan ( Binatang, Tumbuh-tumbuhan, Alam sekitar).

Disamping lingkungan harus bersih, juga harus menyayangi binatang piaraan dengan memberi makan dan minum. Lingkungan harus bersih baik di rumah maupun di sekolah karena sangat berpengaruh terhadap kesehatan kita. Tumbuh-tumbuhan mesti ditata agar dapat membuat keindahan dan kesejukan. Perhatikan kelestarian lingkungan, karena lingkungan yang lestari dapat memberikan keindahan. Cintailah lingkungan karena banyak memberi manfaat kepada diri sendiri.

Bila ajaran Tat Twam Asi dapat diimplementasikan dalam kehidupan sehari-hari kepada umat manusia secara menyeluruh dan sungguh-sungguh, dalam sifat dan prilaku kita maka kehidupan ini akan menjadi harmonis. Satu dengan yang lainnya diantara kita dapat hidup saling menghormati, mengasihi dan damai.

Seperti disebutkan dalam tata susila Hindu bahwa yang menjadi dasar dan pedoman ajaran Tat Twam Asi diantaranya adalah :

1. Memandang semua manusia sama

Didalam diri manusia ada dua sifat yang antagonis dan sangat kontradiktif yakni sifat kedewataan (daiwi sampat) yaitu sifat-sifat yang baik dan sifat-sfat keraksasaan, keangkara murkaan (asuri sampat) yaitu sifat-sifat buruk. Jika dalam kehidupan manusia ingin mendapatkan kedamaian hidup, maka usahakanlah terus untuk menumbuh kembangkan sifat-sifat kedewataan.

Didalam kitab Yajur Weda 40.7 disebutkan :

Seseorang yang menganggap seluruh umat manusia memiliki atman yang sama dan dapat 
melihat semua manusia sebgai saudaranya, orang tersebut tidak terikat dalam ikatan dan bebas dari kesedihan. Adapun yang tersirat dari mantra tersebut yaitu :

Atman di dalam diri manusia adalah sama. Atman adalah percikan terkecil dari Brahman dan Atman adalah bagian dari Brahman. Atma dan Brahman adalah satu kesatuan (Atman Brahman Aikyam). Dengan kata lain, bila dipandang atau dipahami dari sudut Atman, maka Aku adalah Atma, semua umat manusia adalah Atma. Atman itu satu, maka Aku satu dengan semua umat manusia. Jadi yang membedakan manusia satu dengan yang lain karena pikiran (manah) manusia.

- Umat manusia di seluruh dunia ini adalah sebuah keluarga besar yang mempunyai keinginan hidup berdampingan secara damai di muka bumi.

2. Melaksanakan Tri Kaya parisudha (tiga perilaku yang disucikan)

Tri artinya tiga, Kaya artinya gerak, usaha dan Parisudha artinya suci atau kesucian. Jadi Tri Kaya Parisudha artinya tiga gerak perbuatan dan tingkah laku manusia yang harus disucikan dengan sebaik-baiknya, yaitu :

1) Manacika : berpikir / pikiran yang baik dan suci.

2) Wacika : berkata / perkataan yang baik dan benar

3) Kayika : berbuat / laksana yang baik dan jujur

Dengan adanya pikiran yang baik dan suci akan timbul perkataan yang baik. Dengan adanya pikiran dan perkataan yang baik dan suci akan terwujudlah perbuatan yang baik dan benar juga.

Maka dari itulah kita harus memupuk persatuan dan kesatuan pikiran, perkataan dan perbuatan yang baik dan suci berethika (bersusila).

Dari Tri Kaya Parisudha timbullah sepuluh macam pengendalian diri yang disebut Karma Patha, yaitu terdiri dari : a) Tiga macam berdasarkan pikiran

b) Empat macam berdasarkan perkataan

c) Tiga macam berdasarkan perbuatan/prilaku

Tiga macam yang berdasarkan pikiran yaitu :

- Tidak menginginkan dan tidak dengki terhadap milik orang lain.

Perbuatan ini dapat menimbulkan kecendrungan yang negatif, seperti rasa iri. Hidup dalam keadaan iri akan membuat kita menderita. Sifat iri ini timbul karena kurang tumbuhnya rasa kasih sayang terhadap sesama. Pikiran akan menjadi suci (ning) bila tidak menginginkan milik orang lain serta tidak membenci milik orang lain.

- Tidak berpikiran buruk terhadap orang lain dan makhluk lain.

Semua makhluk hidup berasal dari atma yang sama, yaitu Ida Sang Hyang Widhi. Beliau menakdirkan, ada makhluk yang bernasib baik dan ada yang bernasib buruk sesuai karmanya masing-masing. Orang yang hidup sehat dan berumur panjang salah satu penyebabnya karena ia menumbuhkan rasa cinta kasih kepada semua makhluk.

- Tidak mengingkari adanya hukum karmaphala

Hal ini sangat penting untuk dipahami dan dihayati, siapa yang berbuat baik akan mendapat pahala yang baik dan siapa yang berbuat buruk sudah dapat dipastikan akan mendapatkan hasil yang buruk. Harus kita yakini benar kesungguhan hukum Tuhan tersebut. Meskipun kita melihat orang berbuat buruk pada saat ini dan kenyataannya ia bernasib baik, itupun karena hukum karmaphala juga. Nasib baik yang ia terima saat ini pasti karena perbuatan baik sebelumnya yang ia lakukan. Sedangkan perbuatan buruk yang dilakukan saat ini sudah pasti akibatnya akan diterima kelak, entah kapan. Orang yang selalu berusaha mengendalikan pikiran dan diarahkan pada niat suci akan jarang mendapat persoalan sulit dalam kehidupannya di masyarakat. 
Memang telah menjadi kenyataan apabila perhatian benar-benar segala perbuatan manusia di dunia ini berpangkal pada pikiran. Pikiranlah yang merupakan pangkal segala perbuatan. Pikiran yang baik akan menimbulkan perbuatan baik dan pikiran yang tak baik akan menimbulkan perbuatan yang tak baik pula. Oleh karena itu kita wajib berusaha selalu mengontrol dan mengendalikan jalan pikiran kita agar tidak bergerak kearah yang tidak baik. Kalau sifat dengki, loba, irihati, marah dan nafsu-nafsu yang rendah timbul dari pikiran yang tak terkontrol dan tidak terkendalikan. Seperti disebutkan dalam kitab Sarasamuscaya seperti berikut ini :

"Apan ikang manah ngaranya ya ika witning indriya,

maprawreti ta ya ring Çubhãçubha karma, matangnyan ikang manah juga prihen kakretannya sakareng"

(Sarasamuscaya,VII,86).

Maksudnya :

Oleh karena pikiran itu merupakan asal nafsu dan asal mulanya perbuatan yang baik maupun yang buruk, maka dari itu usahakanlah pengendalian pikiran itu dari sekarang juga. Jadi singkatnya pengendalian pikiran dan nafsu itulah factor terpenting didalam kehidupan manusia.

Empat macam berdasarkan perkataan, yaitu :

- Tidak suka mencaci maki / berkata jahat (Ujar ahala).

Mencaci maki atau berkata jahat yang terucap akan dapat mencemarkan vibrasi kesucian. Karena dalam kata-kata yang jahat terdapat gelombang yang mengganggu keseimbangan vibrasi kesucian.

- Tidak berkata kasar (Ujar aprgas).

Kata-kata kasar sangat menyakitkan bagi yang mendengarkan. Perlu diperhatikan, meskipun niat baik, jika diucapkan dengan kata-kata yang kasar maka niat baik itu akan turun nilainya/menjadi tidak baik. Bagi yang mempunyai kebiasaan berkata kasar, berjuanglah untuk merubahnya.
- Tidak memfitnah (Rajapisuna).

Ada pepatah mengatakan fitnah itu lebih kejam dari pembunuhan. Dalam persaingan hidup, orang sering melakukan persaingan dengan cara memfitnah agar lawan dengan mudah dikalahkan. Kalau tidak mampu berbuat lebih dari kenyataan maka fitnahpun akan untuk senjata agar kelihatan lebih dari yang lain. Cegahlah lidah agar tidak mengucapkan kata-kata fitnah.

- Tidak ingkar pada janji dan ucapan.

Berbohong sering dilakukan untuk menutupi kekurangan diri. Agar kelihatan lebih dari orang lain berbohongpun sering dilakukan. Menghilangkan kebiasaan berbohong ini haruslah dibiasakan untuk rela menerima apa adanya sesuai dengan karma kita.

Demikianlah empat hal yang harus dibiasakan agar tidak keluar dari lidah kita kata-kata yang tidak baik atau menyakitkan. Kata-kata ibarat pisau bermata dua, di satu pihak bisa mendatangkan kebahagiaan dan di lain pihak bisa mendatangkan penderitaan bahkan kematian, seperti termuat dalam kitab Nitisastra berikut ini :

"Wasita nimitanta manemu laksmi, Wasita nimitanta pati kapangguh, Wasita nimitanta manemu duhka, Wasita nimitanta manemu mitra"

(Nitiswastra,V.3)

Maksudnya :

Oleh perkataan engkau akan mendapatkan bahagia,

Oleh perkataan engkau akan menemui ajalmu,

Oleh perkataan engkau akan mendapatkan kesusahan, dan

Oleh perkataan engkau akan mendapatkan sahabat.

Tiga macam pengendalian yang berdasarkan perbuatan, yaitu :

- Tidak menyakiti atau tidak membunuh makhluk lain (Ahimsa). 
Pada umumnya ahimsa diartikan tidak boleh membunuh atau tidak menyakiti secara fisik, tetapi bila segala prilaku itumenyebabkan orang lain sakit hatinya juga tergolong perbuatan himsa. Ahimsa tergolong sifat-sifat kedewataan (Daiwi Sampad). Orang yang berhasil menumbuhkembangkan sifat-sifat kedewataan akan lebih mudah meraih karunia dari Ida Sang Hyang Widhi Wasa. Dengan terpeliharanya ajaran ahimsa berarti tidak ada kekerasan dalam kehidupan bersama di dunia ini. Hakikat dari manusia hidup di dunia ini adalah bersaudara.

- Tidak mencuri, merampok, mengambil hak orang lain secara tidak sah.

Intinya seseorang tidak terlalu terikat oleh benda-benda duniawi, serta senang melakukan amal. Jika kesucian perbuatan tidak dijaga akan berakibat terjadinya pemaksaan terhadap oaring lain yang berimbas kepada tidak adanya hubungan yang harmonis sehingga tidak akan tercapai kedamaian di hati, kedamaian di bumi dan kedamaian di akhirat.

- Tidak berzinah.

Berzinah merupakan perbuatan yang sangat hina dan terkutuk. Perbuatan ini harus dikendalikan karena bisa menimbulkan kemerosotan moral. Berzinah artinya sikap suka memperkosa wanita atau istri orang lain. Larangan melakukan zinah itu memang wajar, karena jika dibiarkan maka kemerosotan moral akan makin memuncak. Banyak terjadi pelacuran atau tuna susila maka kehidupan kita sebagai manusia yang menjunjung tinggi budaya dan agama menjadi hancur. Adapun yang termasuk perbuatan berzinah (paradara) adalah :

Mengadakan hubungan kelamin dengan suami/istri orang lain

Mengadakan hubungan kelamin (sex) antara pria dan wanita dengan jalan tidak sah

Mengadakan hubungan kelamin dengan paksa artinya tidak atas dasar cinta sama cinta (perkosaan)

- Hal ini sangat ditentukan oleh proses berpikir seseorang. Artinya bila pikirannya dilandasi oleh niat yang baik, itikad yang baik, maka seseorang akan mampu mengendali-kan indrianya dan akan menyebabkan orang lain senang dan bahagia, seperti diuraikan dalam kitab Sarasamuscaya, berikut ini :

"Nihan yan tan ulahakena, syamatimati mangahalahal, siparadara,

nahan tan telu ulahakena ring asing ring parihasa, ring apatkala,

ri pangipyan tuwi singgahana jugeka."

(Sarasamuscaya,76).

Maksudnya :

Inilah yang tidak patut dilakukan : membunuh, mencuri, berbuat zinah, ketiganya itu jangan hendaknya dilakukan terhadap siapapun, baik secara berolok-olok, bersendagurau, baik dalam keadaan dirundung malang, keadaan darurat dalam khayalan sekalipun, hendaknya dihindari saja ketiganya itu.

Didalam ajaran agama Hindu ditandaskan bahwa segala perbuatan baik ataupun buruk yang dilakukan oleh manusia walaupun hanya baru dalam angan-angan saja, pasti akan berpahala. Dalam pribahasa dikatakan : "Ala ulah, ala tinemu, ayu kinardi, ayu pinanggih."

Yang artinya apapun yang kita perbuat begitulah hasilnya. Buruk dibuat buruk hasilnya. Baik dibuat pasti baik hasilnya. Sebagaimana halnya kita menanam bibit padi pastilah padi (beras) hasilnya tidak mungkin orang menanam bibit padi akan menghasilkan jagung atau ketela.

Demikianlah, maka kesimpulannya bahwa barang siapa yang menjunjung tinggi dan melaksanakan ajaran Tri Kaya Parisudha dengan sungguh-sungguh akhirnya ia pasti akan berhasil mencapai kesempurnaan yang tertinggi.

\section{Merasakan penderitaan orang lain}

Ukuran rasa kemanusiaan seseorang adalah apabila dia dapat merasakan penderitaan orang lain sebagai penderitaannya. Karena dirasakan 
sebagai penderitaannya maka ia sendiri akan ikut aktif menanggulangi penderitaan orang lain. Ikut serta menanggulangi penderitaan orang lain adalah sesuai dengan kemampuan dan swadharma masing-masing. Dalam system kehidupan yang modern dewasa ini sesungguhnya banyak pihak yang mendapat kesempatan untuk mengamalkan rasa kemanusiaannya. Sayang kebanyakan orang tidak menggunakan kesempatan ini untuk mengamalkan rasa kemanusiaannya. Justru penderitaan orang lain sering dijadikan ajang untuk mencari keuntungan guna memperkaya diri sendiri. Sebuah ajaran tentang refleksi cinta kasih, tidak hanya kepada sesama manusia tetapi juga kepada semua makhluk.

Dengan menyadari bahwa manusia dapat melihat dirinya pada makhluk lain, diajarkan untuk menjauhkan diri dari sifat ego. Dengan menyadari orang lain adalah bagian dari diri, maka seseorang tidak akan mudah melakukan tindakan-tindakan yang dapat menyakiti orang lain karena menyakiti orang lain berarti menyakiti diri sendiri. Melalui kesadaran tersebut sehingga diharapkan yang akan tumbuh dalam diri kita adalah sikap saling mengasihi antar sesama dan mahkluk hidup lainnya. Sebagai makhluk sosial umat Hindu tidak semata-semata rukun dengan sesama manusia. Tetapi juga harus harmonis secara vertical dan horizontal. Secara vertikal (ke atas) dekat dengan Tuhan sebagai Raja Alam Semesta (Prajapati), horizontal (kebawah) menanamkan rasa kasih sayang pada semua makhluk secara horizontal mengembangkan kerukunan dengan sesama manusia. Dalam ajaran Kitab suci Veda, agar terciptanya kehidupan yang Kreta Jagadhita dijelaskan secara gamblang dalam ajaran "Tat twam asi". Ajaran "Tat twam asi" merupakan ajaran sosial tanpa batas. Saya adalah kamu, dan sebaliknya kamu adalah saya, dan segala makhluk adalah sama sehingga menolong orang lain berarti menolong diri sendiri dan menyakiti orang lain berarti pula menyakiti diri sendiri (Upadesa, 2002: 42).
Antara saya dan kamu sesungguhnya bersaudara. Hakikat atman yang menjadikan hidup diantara saya dan kamu berasal dari satu sumber yaitu Tuhan. Atman yang menghidupkan tubuh makhluk hidup merupakan percikan terkecil dari Tuhan. Kita sama-sama makhluk ciptaan Tuhan. Sesungguhnya filsafat "Tat twam asi" ini mengandung makna yang sangat dalam. Tatwam asi mengajarkan agar kita senantiasa mengasihi orang lain atau menyayangi makhluk lainnya. Bila diri kita sendiri tidak merasa senang disakiti apa bedanya dengan orang lain. Maka dari itu janganlah sekali-kali menyakiti hati orang lain. Dan sebaliknya bantulah orang lain sedapat mungkin kamu membantunya, karena sebenarnya semua tindakan kita juga untuk kita sendiri. Bila dihayati dan diamalkan dengnan baik, maka akan terwujud suatu kerukunan. Dalam upanisad dikatakan: "Brahma atma aikhyam", yang artinya Brahman (Tuhan) dan atman sama. Sistem kekeluargaan dan kekerabatan adalah sebuah ciri yang melekat pada seluruh kebudayaan di Indonesia. Tidak terkecuali pada masyarakat Hindu di Bali. Sistem tersebut menjadi hukum adat bagi terciptanya hubungan antara manusia dengan manusia.Hubungan antar manusia dalam ajaran Hindu di Bali tertuang dalam filosofi "Tat twam asi" sebagai dasar hukum. Sesuai dengan pengertiannya tat twam asi "ia adalah kamu". Saya adalah kamu dan segala mahkluk adalah sama. Ini berarti menolong orang lain berarti menolong diri sendiri. Dan menyakiti orang lain berarti pula menyakiti diri sendiri. Prinsip dasar Tat twam asi ini dalam kehidupan adat Bali diberi pengertian ke dalam asas-asas sebagai berikut.

a. Asas suka duka, artinya dalam suka dan duka dirasakan bersama-sama.

b. Asas paras paros, artinya orang lain adalah bagian dari diri sendiri dan diri sendiri adalah bagian dari orang lain. 
c. Asas salunglung sabayantaka, artinya baik buruk, mati hidup ditanggung bersama.

d. Asas saling asah, saling asih, saling asuh, artinya saling menyayangi atau mencintai, saling memberi dan mengoreksi, serta saling tolong menolong antar sesama hidup.

Ajaran tat twam asi mengajak setiap orang penganut agama untuk turut merasakan apa yang sedang dirasakan orang lain. Seseorang bila menyakiti orang lain sebenarnya ia telah bertindak menyakiti atau menyiksa dirinya sendiri, dan sebaliknya bila telah membuat orang lain menjadi senang dan bahagia, maka sesungguhnya dirinya sendirilah yang ikut merasakan kebahagiaan itu juga. Tat twam asi merupakan kata kunci untuk dapat membina agar terjalinnya hubungan yang serasi atas dasar "asah, asih, dan asuh" di antara sesama hidup. Dalam Sarasamuscaya: 317, menyatakan:

"Orang arif bijaksana melihat semuanya sama, baik kepada brahmana budiman yang rendah hati, maupun terhadap makhluk hidup lainnya, orang yang hina papa sekalipun, walaupun perbuatan jahat yang dilakukan orang terhadap dirimu, perbuatan seperti orang sadhu hendaknya sebagai balasanmu. Janganlah sekalikali membalas dengan perbuatan jahat, sebab orang yang berhasrat berbuat kejahatan itu pada hakekatnya akan menghancurkan dirinya sendiri"

Dalam kehidupan, apabila konsep Tat twam asi tidak diterapkan, kesejahteraan tidak akan pernah tercapai, karena egoisme yang tinggi akan memengaruhi setiap individu. Adapun contoh konsep Tat twam asill tidak diterapkan, yaitu adanya konflik antar desa atau antar banjar menjadi bukti nyata. Ketika Tat twam asi tidak bisa dijadikan acuan, konflik akan makin melebar. Dampaknya akan ada kasepekang (pengucilan). Kalau sudah kasepekang, sembahyang ke pura pun tidak boleh, apalagi mau ngaben. Dari contoh ini dapat kita lihat, apabila ajaran Tat twam asi tidak bisa kita terapkan tentunya hanya akan berdampak buruk bagi kehidupan bermasyarakat, Kehidupan sosial masyarakat tentunya tidak terlepas dengan perkembangan kehidupan beragama. Hal ini menjadi satu kesatuan yang tidak dapat dipisahkan satu dengan yang lain. Agama menjadi keyakinan setiap individu sehingga melekat di dalam diri, bahkan ketika mereka hidup dalam sosial masyarakat yang beragam. Khususnya Agama Hindu, perkembanganya tidak akan pernah meninggalkan sisi kehidupan pribadi, sosial, ekonomi, pengetahuan, pemahaman serta pola pikir individu yang menganut keyakinan Hindu itu sendiri.Penganut umat Hindu pun beragam dari latar belakang suku yang berbeda, misalnya: Suku Jawa, Bali, Batak, Dayak, Banjar, sunda, dll. Di Indonesia, umat Hindu mayoritas dianut oleh keturunan suku Bali, sisanya Jawa dan suku-suku lain yang masih memegang teguh ajaran dharma ini. Berdasarkan satu sisi penganut saja Hindu sudah jelas sekali mengajarkan adanya kebegaraman.

Umat Hindu etnis Bali yang mampu hidup berdampingan di seluruh pelosok Nusantara sampai saat ini. Ciri khas umat Hindu adalah damai, cinta, kasih, tidak menyakiti, dan beragam sehingga mampu menciptakan kehidupan sosial yang harmonis. Hal ini menandakan bahwa Umat Hindu sebagian besar telah mampu menjabarkan arti dari keberagaman melalui ajarannya dan perilaku kesehariannya. Namun, belum keseluruhan umat Hindu mampu menjabarkan konsep keberagaman ini dengan baik dalam kehidupan sehari-hari. Seperti halnya umat Hindu yang ada di daerah-daerah pelosok ataupun daerah transmigrasi yang jauh sekali dengan sentuhan pembainaan mental maupun spiritual. Walaupun secara ekonomi mampu dan mencukupi namun terkadang kebutuhan mental dan spiritual 
belum tercukupi dengan baik. Hal ini yang kemudian menyebabkan sikap-sikap eksklusif dalam bermasyarakat. kebanyakan hanya dilihat darimana dia berasal, suku apa, agamanya apa, kaya atau miskin.

Hindu tidak pernah tampil sebagai sosok yang arogan. Doktrin Hinduisme yang pluralisme itu sangat menghargai berbagai theisme atau paham ketuhanan. Doktrin Hinduisme yang pluralis itu tidak pernah mengklaim suatu kebenaran sebagai kebenaran yang hanya menjadi milikinya sendiri. Hinduisme tidak pernah mengadili atau menghina kebenaran lain. Hinduisme tidak pernah melihat orang yang berada di luarnya sebagai orang yang dipandang sebelah mata oleh Tuhan. Hinduisme berpandangan bahwa setiap orang dan kelompok orang bergerak maju dari kebenaran yang sederhana menuju kebenaran yang lebih tinggi hingga kebenaran tertinggi. Untuk sampai pada anak tangga yang teratas seseorang mesti menginjakkan kakinya terlebih dahulu pada anak tangga pertama. Mustahil bagi seseorang untuk sampai pada tangga teratas tanpa melalui anak tangga pertama. Setiap orang akan memperoleh kesempatan yang sama dalam waktu yang berbedabeda sesuai dengan karma wesana yang nantinya akan menentukan tingkat kemampuan mereka dalam mencari kebenaran. Demikian juga setiap orang akan memiliki kesempatan yang sama dalam waktu yang berbeda-beda untuk sampai pada anak tangga teratas dari sebuah kebenaran. Oleh sebab itu antara kebenaran-kebenaran itu tidak harus saling intervensi, sebab kebenaran itu selalu bergerak maju dari yang sederhana (rendah) ke yang lebih tinggi. Oleh sebab itu pula Hinduisme tak pernah, cemas, gelisah, atau berburuk sangka terhadap berbagai wacana ataupun penampilan dari berbagai macam keyakinan. Hinduisme sebagai kepercayaan spiritual yang paling tua di dunia dan sangat dewasa dalam melihat pluralisme kebenaran. Lain halnya dengan yang lain sangat cemas dan ragu menerima hembusan angin pluralisme, sebab mereka amat takut jika kepercayaannya tidak lagi dianggap sebagai suatu kebenaran utama. Namun harus diingat pluralisme dalam Hindu bukan berarti menyamakan ratakan Hindu dengan yang lain, tapi dalam artian bahwa Hindu tidak pernah menyatakan konsep kepercayaan yang lain sebagai suatu yang salah atau sesat.

Berdasarkan arti dari kata tat twam asi tersebut dapat diartikan bahwa umat Hindu menganggap bahwa kita semua pada dasarnya adalah sama bersumber dari satu Tuhan, dari pengertian itu juga umat Hindu sangat menghargai sesama manusia dan semua makhluk ciptaan Tuhan. Berkaitan dengan pluralisme dalam ajaran agama Hindu juga mempunyai slogan yang dikutip dari sastra suci yang berbuyi "Vasu Daiva Kutumbakam" yang berarti, "Kita Semua Bersaudara”, jadi umat hindu menganggap bahwa kita semua adalah saudara tanpa membeda-bedakan suku, ras, antar golongan maupun agama. Dalam Bhagavadgita IX.29, dijelaskan:

"samo ham sarva-bhūteșu na me dveșyo sti na priyah ye bhajanti tu mām bhaktyā mayi te teșu cāpy aham"

Artinya :

Aku tidak pernah iri dan selalu bersikap adil terhadap semua makhluk. BagiKu tidak ada yang paling Ku-benci dan tidak ada yang paling Aku kasihi. Tetapi yang berbakti kepada-Ku, dengan penuh pengabdian, mereka berada pada-Ku dan Aku bersamanya pula.

Melalui satra suci Bhagavadgita, Tuhan telah mengajarkan sebuah laku yang mulia dan penuh dengan kebijaksanaan, tentang hakikat terlahir, hidup, serta berkarma dan membawa sang Jiwa yang bersemayam di dalam badan untuk tidak 
membedakan mana yang lebih dikasihi ataupun yang dibenci, hanya saja bagaimana sang ciptaan mampu menempatkan diri serta, melakukan apa yang seharusnya dilakukan sebagai ciptaan.

Dengan keberagaman agama yang ada di Indonesia yang terdiri dari Islam, Katolik, Kristen, Hindu, Budha, Konghuchu, sampai saat ini mampu berjalan harmonis dan senantiasa saling menghormati. Panasnya suasana politik akhirakhir ini, mencerminkan betapa kita perlu kembali ke dalam diri melalui keyakinan atau agama kita. Tentunya masing-masing agama mengajarkan untuk saling menjaga diri, berperilaku yang baik, tidak saling menyalahkan, saling menghargai, menjunjung tinggi nilai kemanusiaan dan tentunya melakukan keyakinan dengan baik. Inilah pentingnya pengetahuan dan pemahaman dalam hidup ber-Pancasila dan Ber-Bhineka Tunggal Ika, jangan sampai karena perbedaan pandangan politik, keadaan ekonomi yang sulit, pergaulan, kita sebagai umat Hindu yang memegang teguh spirit pluralisme salah menempatkan diri serta ikut larut dalam suasana yang menghancurkan kedaulatan. Kita sebagai umat Hindu seharusnya mampu membawa angin segar kemajemukan dan keBhinekaan. Apa yang sesungguhnya diajarkan oleh agama Hindu adalah pluralisme agama, bukan keperluan untuk membuat semua agama sama, yang adalah intoleran terhadap perbedaanperbedaan agama yang sering sama sekali tidak kecil atau tidak penting. Pluralisme agama, pada sisi lain, adalah toleran atas perbedaanperbedaan agama. Ia tidak mereduksi semua agama ke dalam satu model bersama. Ia membiarkan perbedaan-perbedaan mereka kelihatan dengan jelas sebagaimana mereka adanya dan tidak berupaya menutupinya dengan satu kerudung kesatuan. Pluralisme mengatakan bahwa adalah baik bagi kita untuk mempunyai perbedaaan atau bahkan pandangan-pandangan yang bertentangan mengenai agama dan ini tidak harus menjadi satu masalah. Satu pandangan agama pluralistik menerima bahwa ada banyak jalan. Agama yang berbeda jalan atau cara-cara ini mempunyai berbagai derajat perbedaan-perbedaan di antara mereka, beberapa mungkin kecil, beberapa mungkin besar. Jalan yang berbeda akan menarik bagi individu-individu yang berbeda sesuai dengan berbagai temperamen atau derajat dari perkembangan mereka, yang akan sangat berbeda dan selalu berubah. Beberapa dari jalan atau caracara ini mungkin baik atau mulia, atau mungkin menjijikkan. Beberapa mungkin menarik untuk temperamen agama yang rendah, yang lain mungkin menarik bagi satu level realisasi spiritual.

Agama-agama harus membangun kemanusiaan, inilah Bhineka Tunggal Ika dalam beragama. Pluralisme mengatakan bahwa adalah baik bagi kita untuk mempunyai perbedaaan. Dengan kata lain agama-agama harus membangun kemanusiaan yang telah nyata tercermin dalam ajaran Hindu. Spirit "Tat twam asi", dan "Vasudaiwa Kutum Bakam" harus menjadi dasar kuat menjalankan Dharma Agama dan Dharma Negara. Kemajemukan dalam umat beragama hendaknya senantiasa diawasi dan selalu didukung oleh semua lini baik dari pemerintah, tokoh-tokoh agama serta masyarakat itu sendiri. pembinaan di masing-masing agama harus lebih intensif terutama pemahaman mengenai perbedaan serta kemajemukan dan pluralisme agama yang memang harus terjadi di Indonesia.

Ajaran "Tat tvam asi" dapat dijadikan acuan dan solusi dari masalah yg terjadi dalam lingkungan kehidupan manusia masyarakat yang berselisih paham, menghadapi silang sengkata yang tidak kunjung padam, bahkan sampai tibul percekcokan Pertengkaran bahkan perkelahian dan peperangan.karna ajaran ini mengandung nilai yang memandang setiap makhluk hakikatnya sama, karena ada atma yang menghidupkan setiap makhluk dan memahami bahwa semua 
makhluk adalah bersaudara, bagaikan sebuah keluarga sehingga semestinya ada kesetaraan dan penghargaan terhadap hak-hak setiap orang. Spirit toleransi dan penghargaan atas perbedaan inilah yang dijaga oleh masyarakat Hindu Bali agarnilai kearifan lokal dalam ajaran agama Hindu tetap bisa mewujudkan keharmonisan dalam hidup beragama. Bali sendiri tidak bisa membendung pendatang yang berbeda latar budaya, agama, untuk datang dan mendiami Bali. Bukan perbedaan ini lantas menjadikan kita ingin terus berdebat, menguasai, melakukan gerakan-gerakan intoleran. Tat twam asi menjadi simbol budaya yang bisa mengekang semua keinginan intoleran tersebut. Sebab, tat twam asi memberikan kita pemahaman bahwa ketika seseorang menyakiti orang lain, menyinggung, bahkan mengamcam keberdaan orang lain, maka suatu saat kondisi yang demikian pula akan datang pada diri seseorang tersebut. Untuk itulah, senantiasa manusia diajarkan untuk tidak melakukan amcaman kejahatan kepada orang lain, karena dirinya sendiri tidak menginginkan hal yang serupa terjadi padanya. Konsep nilai tat twam asi ini sangat sederhana. Namun, implementasi dalam hidup harus benarbenar diaplikasikan secara sungguh-sungguh dan bermakna.

Wujud nyata dari ajaran Tat twam asi ini dapat dicermati dalam kehidupan dan perilaku keseharian dari umat manusia. Manusia dalam hidupnya memiliki berbagai macam kebutuhan yang dimotivasi oleh keinginan (kama) setiap manusia. Sebutan manusia sebagai makhluk hidup itu banyak jenis, sifat, dan ragamnya seperti: manusia sebagai makhluk individu, sosial, religius, ekonomis, budaya dan lain lainnya. Apabila semua itu harus dapat dipenuhi oleh manusia secara menyeluruh dan bersamaan tanpa memperhitungkan situasi dan kondisinya serta keterbatasan yang dimiliknya, betapa susah dan payah yang dirasakan oleh individu yang bersangkutan. Disinilah manusia perlu mengenal dan melaksanakan rasa kebersamaan, sehingga seberapa berat masalah yang dihadapinya akan terasa ringan. Dengan memahami serta mengamalkan ajaran Tat twam asi, manusia akan dapat merasakan berat dan ringan dalam hidup dan kehidupan ini. Bila ajaran Tat twam asi dapat diimplementasikan dalam kehidupan sehari-hari oleh masyarakat secara menyeluruh dan sungguhsungguh, dalam sifat dan prilaku kita maka kehidupan ini akan menjadi sangat harmonis. Satu dengan yang lainnya diantara dapat hidup saling menghormati, mengisi dan damai. Makna mendasar yang dapat dipetik dari Tat twam asi tersebut adalah bagaimana menyayangi diri sendiri demikian juga menyayangi orang lain bahkan lingkungan sekalipun. Atas dasar itu maka tindakan hormat menghormati sangat diperlukan bahkan harus dilakukan dalam kehidupan seharihari baik dalam kehidupan bermasyarakat, berbangsa, dan bernegara. Ajaran Tat twam asi sangat selaras dengan ideologi Negara Indonesia yaitu pancasila. Dengan demikian setiap warga Negara mempunyai hak untuk mengaktualisasikan ajarannya ditengah - tengah masyarakat sepanjang tidak bertentangan dengan tatanan yang berlaku di masyarakat tersebut serta tetap mengutamakan rasa persatuan dan kesatuan bangsa.

\section{Simpulan}

Mahavakya tat twam asi termuat dalam chandogya upanisad " yang berarti: Dikaulah itu; Dikaulah semua itu; Semua makhluk adalah Engkau. Engkau awal mula jiwatman (roh) dan zat (prakrti) semua makhluk. Aku ini adalah makhluk yang berasal dari Mu. Oleh karena itu jiwatmaku dan prakrtiku tunggal dengan jiwatman semua makhluk, dan Dikau sebagai sumberku dan sumber semua makhluk. Oleh karena itu aku adalah Engkau,begitupun sebaliknya. Ajaran tat twam asi mengajak setiap orang penganut agama 
untuk turut merasakan apa yang sedang dirasakan orang lain. Seseorang bila menyakiti orang lain sebenarnya ia telah bertindak menyakiti atau menyiksa dirinya sendiri, dan sebaliknya bila telah membuat orang lain menjadi senang dan bahagia, maka sesungguhnya dirinya sendirilah yang ikut merasakan kebahagiaan itu juga. Ajaran "Tat tvam asi" dapat dijadikan acuan dan solusi dari segala masalah yg terjadi dalam lingkungan kehidupan manusia karna ajaran ini mengandung nilai yang memandang setiap makhluk hakikatnya sama, karena ada atma yang menghidupkan setiap makhluk dan memahami bahwa semua makhluk adalah bersaudara, bagaikan sebuah keluarga sehingga semestinya ada kesetaraan dan penghargaan terhadap hak-hak setiap orang. Spirit toleransi dan penghargaan atas perbedaan inilah yang dijaga oleh masyarakat Hindu Bali agar nilai kearifan lokal dalam ajaran agama Hindu tetap bisa mewujudkan keharmonisan dalam hidup beragama. Bali sendiri tidak bisa membendung pendatang yang berbeda latar budaya, agama, untuk datang dan mendiami Bali. Bukan perbedaan ini lantas menjadikan kita ingin terus berdebat, menguasai, melakukan gerakan-gerakan intoleran. Tat twam asi menjadi simbol budaya yang bisa mengekang semua keinginan intoleran tersebut. Sebab, tat twam asi memberikan kita pemahaman bahwa ketika seseorang menyakiti orang lain, menyinggung, bahkan mengamcam keberdaan orang lain, maka suatu saat kondisi yang demikian pula akan datang pada diri seseorang tersebut. Untuk itulah, senantiasa manusia diajarkan untuk tidak melakukan amcaman kejahatan kepada orang lain, karena dirinya sendiri tidak menginginkan hal yang serupa terjadi padanya. Konsep nilai tat twam asi ini sangat sederhana. Namun, implementasi dalam hidup harus benar- benar diaplikasikan secara sungguh-sungguh dan bermakna.

\section{DAFTAR PUSTAKA}

Radhakrishnan.S, 2008. Upanisad Upanisad Utama. Terjemahan Oleh Agung S Mantik. Surabaya: Paramita.

Natal,devi. 2015. tat-twam-asi. Diunduh: 29/10/2018 http://nataldevi.blogspot. com/2015/04/tat- twam-asi.html.

Kusumohamidjojo, Budiono. 1999. Kebhinekaan Masyarakat Indonesia, Suatu Problematik Filsafat Kebudayaan. Jakarta: Gramedia.

Pidarta, I Made. 2000. Hindu Untuk Masyarakat Umum Pada Zaman Pasca Modern. Surabaya: Paramita.

Subagiasta, I Ketut. 2006. Teologi, Filsafat, Etika dan Ritual dalam Suastra Hindu. Surabaya: Paramita

Pascasarjana IHDN Denpasar. Suhardana, Komang. 2010. Tat twam asi. Ajaran Kesamaan Martabat Manusia. Surabaya: Paramita. 